\title{
THE IMPORTANCE OF ACHIEVEMENT GOALS AND ATTITUDES TOWARDS EDUCATION FOR EXPLAINING ADOLESCENTS' CAREER DECISION SELF-EFFICACY
}

\author{
Andreja BUBIĆ \\ Faculty of Humanities and Social Sciences, Split \\ Katarina KRILE, Ivana KUZMAN \\ Croatian Employment Service, Dubrovnik \\ UDK: 331.548-053.6 \\ Izvorni znanstveni rad \\ Primljeno: 9. 4. 2015.
}

Previous research has acknowledged the relevance of individuals' perception of own abilities related to the vocational domain, namely career decision self-efficacy beliefs, for their professional success. In the present study, such beliefs were examined among a group of high school seniors who are facing the process of choosing what professional path to pursue after high school. In addition, students' achievement goals and attitudes towards education were also explored. Results indicate mastery approach, performance avoidance and work avoidance goals, as well as participation in extracurricular activities and attitudes towards education, as significant predictors of career decision self-efficacy. Findings indicate the relevance of academic experiences for the development of career decision self-efficacy and provide novel evidence regarding the complex relationship between individuals' educational and vocational considerations, and may be informative for designing future vocational guidance interventions targeted at adolescents transitioning into colleges or the job market, or individuals undergoing similar occupational transitions.

Keywords: achievement goals, attitudes towards education, career decision self-efficacy, career development

$\triangle \quad$ Andreja Bubić, Chair for Psychology, Faculty of Humanities and Social Sciences, University of Split, Sinjska 2, 21000 Split, Croatia. E-mail: abubic@ffst.hr 


\section{INTRODUCTION}

Individuals' abilities to successfully direct and manage their professional paths represent very important competencies that are becoming more and more valuable in the modern world. We all frequently encounter advice regarding the best ways of behaving at job interviews and witness an increase in the number of vocational guidance centers as well as Internet-based distance career counseling programs available for adolescents, students and individuals of all ages (Gysbers, Heppner, \& Johnson, 1998; Sampson, 1999). The nature of professional paths and careers has also changed, as individuals today have more opportunities for lifelong learning and professional transitions (Baruch, 2004; Savickas et al., 2009). In accordance with the increasing importance of developing vocational competencies from an early age, career development represents a process that unfolds throughout one's lifetime and is marked by numerous changes. For instance, whereas children often consider fantasy jobs or professions present in their daily environment such as their parents' occupations, adolescents are more aware of their own preferences and have more focused and realistic career considerations (Auger, Blackhurst, \& Wahl, 2005; Hartung, Porfeli, \& Vondracek, 2005; Helwig, 1998; Trice, Hughes, Odom, Woods, \& McClellan, 1995). In addition, adolescents are more active in choosing activities that shape their professional future, which also partly reflects the increased external demands and expectations of their parents, teachers and other relevant persons.

Generally, students finishing high school face a very demanding transition either to college or to the job market that is often accompanied by substantial stress and worries (Creed, Muller, \& Patton, 2003; Gall, Evans, \& Bellerose, 2000; Galotti, 1999). The way adolescents deal with this change is influenced by numerous personal characteristics that include cognitive abilities, decision styles, personality traits or emotional competencies (Brown, 2002; Gati, Landman, Davidovitch, Asulin-Peretz, \& Gadassi, 2010). In addition to these, the relevance of individuals' beliefs regarding own characteristics and competencies necessary for successful career development has been recognized by the social cognitive career theory (Lent, Brown, \& Hackett, 1994, 2002). This theory was originally formulated based on the general social cognitive theory (Bandura, 1986), which has acknowledged that self-efficacy influences our motivations and behaviors in various domains, directing us to approach or avoid certain situations (Bandura, 1989, 2006). Similarly, career decision self-efficacy that unites various beliefs related to individuals' ability to successfully manage career-related behaviors is pertinent for their 
DRUŠ. ISTRAŽ. ZAGREB GOD. 24 (2015), BR. 3 STR. 387-405

BUBIĆ, A., KRILE, K., KUZMAN, I. THE IMPORTANCE OF.. sense of personal agency within the vocational domain (Betz \& Hackett, 2006; Lent \& Brown, 2006). These beliefs influence numerous vocational outcomes including career success and stability, as well as professional success (Betz, 2007; Betz \& Hackett, 1986; Betz \& Voyten, 1997; Gianakos, 1999; Lent \& Brown, 2006). Although the importance of self-efficacy beliefs for successful career management has often been demonstrated, less is known about its development that is dependent on individuals' academic experiences. Specifically, it has previously been suggested that the academic and vocational domains are mutually highly interrelated, and that academic experiences may be seen as precursors of persons' career considerations and behaviors (Brown \& Lent, 2006; Lent \& Brown, 2006; Lent et al., 1994). Therefore, it can be postulated that career competencies and decision-making approaches may be related to the way individuals typically approach academic situations and value learning and education. Although numerous factors might be of relevance in this context, in the present study we have primarily focused on individuals' academic motivation and their attitudes towards the value of education.

With regard to academic motivation, various theoretical conceptualizations have thus far been developed that offer different approaches to this phenomenon. Among them, the expectancy-value theory postulates that two key components determine individuals' engagement in academic situations: their expectations regarding the outcomes and the subjective value of the task (Eccles, 2005; Eccles \& Wigfield, 2002; Wigfield \& Eccles, 2000, 2002). In addition to expectations and values, another crucial component of students' motivation includes achievement goals that reflect the purpose of one's engagement in a certain activity and influence both expectations and values (Eccles, 2005; Wigfield \& Eccles, 2000). According to the $2 \times 2$ achievement goal framework, these goals mutually differ with respect to the standard used for judging one's results as well as their valence (Elliot \& McGregor, 2001). Consequently, it is possible to distinguish between goals directed towards mastering a certain task and those aimed towards showing one's more superior performance when compared to others', as well as more positive goals directed towards achieving success and more negative ones directed towards avoiding failure (Elliot \& McGregor, 2001). In addition to these, some authors have suggested that a general tendency to avoid work should also be viewed as a separate goal that may be distinguished from those previously described (Kaliski, Finney, \& Horst, 2006; Nicholls, Cobb, Wood, Yackel, E., \& Patashnick, 1990). Numerous studies have indicated that achievement goals are associated with academic emotions, e.g., mas- 
DRUŠ. ISTRAŽ. ZAGREB GOD. 24 (2015), BR. 3, STR. 387-405

BUBIĆ, A., KRILE, K., KUZMAN, I.:

THE IMPORTANCE OF.. tery goals with enjoyment of learning and pride, performance approach goals with pride, and performance avoidance goals with anxiety, hopelessness, and shame, as well as academic achievement, so that better performance in normative tests is most strongly associated with performance approach, and to a lesser degree with mastery goals (Pekrun, Elliot, \& Maier, 2006, 2009). However, despite the previously mentioned interrelatedness between the academic and career domain, their associations with career-related thoughts and behaviors have previously not been elucidated. Therefore, this issue was addressed within the present study that investigated the relationship between achievement goals and career decision self-efficacy beliefs among Croatian adolescents finishing their high school. In doing so, it was hypothesized that achievement goals that have a positive valence, especially mastery approach goals, would be related to higher career decision self-efficacy beliefs.

Furthermore, the present study also investigated the role of individuals' attitudes toward education in this context, as their relevance has previously been established with regard to students' learning, motivation as well as other educational outcomes (McNeely, Nonnemaker, \& Blum, 2002; Whitlock, 2006). Specifically, it has been demonstrated that students' perception of the relevance of education for their future represents a significant predictor of academic achievement, achievement orientations and school discipline (Raboteg-Šarić, Šakić, \& Brajša-Žganec, 2009). Consequently, this factor was included in the present study where it was hypothesized that more positive attitudes towards the relevance of education would be associated with higher career decision self-efficacy as both of these constructs reflect students' awareness and general orientation towards their professional future.

Moreover, the present study also assessed the relevance of several other factors that may influence participants' career decision self-efficacy. First, we considered the role of gender, taking into account previous studies that have indicated gender differences related to the career decision-making process (Gati et al., 2010; Gati, Osipow, Krausz, \& Saka, 2000; Mau, 2000). Consequently, in the present study we expected that girls would have higher career decision self-efficacy scores. In addition, we also assessed the relevance of the type of attended schools, as this factor often determines some features of career opportunities that are available to students after graduating. The participants of the present study were enrolled into four different high schools in Croatia, namely one gymnasium that provides general education with little specialization and three more specialized vocational schools that all differ with respect to their organization, quality, and specializa- 
DRUŠ. ISTRAŽ. ZAGREB GOD. 24 (2015), BR. 3 STR. 387-405

BUBIĆ, A., KRILE, K., KUZMAN, I.:

THE IMPÓRTANCE OF..

\section{METHOD}

\section{Participants}

tions they provide to students. We hypothesized that the development of vocational self-beliefs might depend on the type of attended school so that students from vocational schools would have higher career decision self-efficacy scores as they had more opportunities to engage in various professional activities during their schooling. Finally, with respect to students' academic experiences, we also considered the relevance of their academic achievement assessed as grade point average (GPA), and enrollment into extracurricular activities. In doing so, it was hypothesized that higher academic achievement as well as participation in extracurricular activities would be identified as significant predictors of students' career decision self-efficacy, because these both provide important bases for developing individuals' self-efficacy beliefs.

Among 361 Croatian high school students who participated in the present study, 125 (34.6\%) were male and $236(65.4 \%)$ female. All participants were enrolled into their senior year of high school, namely one gymnasium $(\mathrm{n}=96 ; 26.6 \%)$ and three vocational (medical, for tourism and economical) schools $(\mathrm{n}=264$; 73.1\%). Students' average GPA in the previous school year was $3.82(S D=0.73)$. A bigger number of participants reported not being enrolled in any extracurricular activities (258; $71.47 \%)$, whereas others mentioned participating in activities such as sports, dancing or learning new languages (102; 28.25\%).

\section{Procedure and Instruments}

Participants were approached at their schools, at the beginning of the second semester of their final grade in high school. They completed the prepared questionnaires: the Achievement Goals Scale (Rovan, 2011), the Attitudes towards Education Scale that was developed for the purpose of the present study, and the short form of the Career Decision Self-Efficacy Scale (Betz, Klein, \& Taylor, 1996). In addition, the participants provided information regarding their gender, current academic achievement (grade point average; GPA) and enrollment into extracurricular activities.

Achievement Goals Scale (Rovan, 2011) is a questionnaire that includes five subscales designed for measuring achievement goals. Four are based on the $2 \times 2$ achievement goal framework (Elliot \& McGregor, 2001): mastery approach that reflects individuals' orientation towards mastering academic tasks, mastery avoidance that reflects individuals' tendency to avoid misunderstanding the task, performance approach that reflects individuals' tendency to attain favorable judg- 
DRUŠ. ISTRAŽ. ZAGREB GOD. 24 (2015), BR. 3, STR. 387-405

BUBIĆ, A., KRILE, K., KUZMAN, I.: THE IMPORTANCE OF.. ments of competence and performance avoidance that reflects individuals' orientation towards avoiding appearing incompetent. In addition, this questionnaire also measures work avoidance as a separate achievement goal that reflects individuals' tendency to accomplish success with minimal investment of effort. Overall, this instrument consists of 15 items, 3 of which are used for measuring each achievement goal - mastery approach (e.g., My goal is to master the lessons taught in this class), mastery avoidance (e.g., I often worry that I will not be able to learn everything I should learn in this class), performance approach (e.g., My goal is to get better grades than other children in school), performance avoidance (e.g., I am worried that I will have lower grades than other students in this class) and work avoidance (e.g., I don't want to do anything more than what I absolutely have to in this class). The participants' task was to rate their agreement with each item using a 5-point Likert type scale (1 - strongly disagree; 5 - strongly agree). Higher results on each subscale reflect a higher degree of each measured achievement goal. Reliability of the calculated subscales (Table 1) were comparable to those previously reported that ranged from 0.68 to 0.87 , with the Work avoidance scale demonstrating the lowest reliability scores (Rovan, 2012; Rovan, Pavlin-Bernardić, \& Vlahović-Štetić, 2013).

Attitudes towards Education Scale is a questionnaire specifically prepared for the purpose of the present study. It measures students' beliefs regarding the importance of education and hard work, and consists of 4 items (e.g., Quality education represents the best basis for life success) that the participants rated on a 5-point scale (1 - strongly disagree; 5 - strongly agree). During the construction of this scale two researchers independently devised a set of 20 candidate items that reflected beliefs regarding the importance of working hard and obtaining a good education for future prosperity. Among these, 4 items were chosen after a discussion and consultation with a third, independent researcher. A higher result on this scale reflects more positive beliefs regarding the importance of getting a good education.

Career Decision Self-Efficacy Scale (CDSES - short form; Betz et al., 1996) is an instrument designed for measuring individuals' beliefs regarding their capacity to successfully complete several tasks necessary for making successful career decisions. A short form of this scale comprising 25 items depicting various tasks that need to be accomplished in order to successfully manage one's career (e.g., How much confidence do you have that you could choose a major or career that will fit your interests?) was administered in the present study. Within this scale, the participants' task was to rate the confidence in their ability to fulfil these tasks using a 5-point scale (1 - no confidence at all; 
DRUŠ. ISTRAŽ. ZAGREB GOD. 24 (2015), BR. 3 STR. 387-405

BUBIĆ, A., KRILE, K., KUZMAN, I.

THE IMPÓRTANCE OF..
5 - complete confidence). In accordance with previous suggestions (Creed, Patton, \& Watson, 2002), this scale was used as a generalized measure of individuals' career decision self-efficacy. A higher score on this scale reflects a higher degree of career decision self-efficacy. Reliability of this instrument (Table 1) was comparable to the previously reported reliabilities typically exceeding 0.90 for the total scale (Betz et al., 1996; Betz \& Voyten, 1997; Creed et al., 2002).

RESULTS

First, descriptive properties and reliabilities of all used instruments were calculated (Table 1).

\begin{tabular}{lrrrrr}
\hline Measure & $M$ & $S D$ & Min & Max & Cronbach $\alpha$ \\
\hline Mastery approach goal & 10.45 & 2.62 & 3 & 16 & 0.68 \\
Mastery avoidance goal & 9.78 & 2.79 & 3 & 15 & 0.69 \\
Performance approach goal & 8.69 & 3.03 & 3 & 15 & 0.77 \\
Performance avoidance goal & 7.58 & 3.19 & 3 & 15 & 0.86 \\
Work avoidance goal & 9.34 & 2.72 & 3 & 15 & 0.66 \\
Attitudes towards education & 15.06 & 3.34 & 4 & 20 & 0.75 \\
Career decision self-efficacy & 89.45 & 15.45 & 25 & 125 & 0.93 \\
\hline
\end{tabular}

(D) TABLE 1 Descriptive Properties and Reliabilities of the Administered Instruments
A correlation analysis was conducted as the first step in exploring the relations among participants' gender, type of attended school, participation in extracurricular activities, GPA, achievement goals, attitudes towards education and career decision self-efficacy (Table 2).

The obtained results revealed moderate positive correlations between mastery approach goals, as well as attitudes towards education, and career decision self-efficacy. Similar correlations were identified with respect to some pairs of achievement goals, in particular performance approach and both types of mastery goals, whereas a stronger correlation was obtained with respect to performance approach and performance avoidance goals. Furthermore, GPA was positively associated with mastery approach goals and attitudes towards education, negatively associated with work avoidance goals, and higher among girls. The remaining correlations are presented in Table 2.

In order to investigate the determinants of career decision self-efficacy, a hierarchical regression analysis was used. Within this analysis gender, type of attended school (gymnasium or vocational school) as well as students' academic achievement (GPA) and participation in extracurricular activities were entered in the first step of the analysis as control variables. Next, five types of achievement goals were entered in the second, whereas attitudes towards education were entered in the last, third step of the analysis (Table 3). 


\begin{tabular}{|c|c|c|c|c|c|c|c|c|c|c|}
\hline & 2 & 3 & 4 & 5 & 6 & 7 & 8 & 9 & 10 & 11 \\
\hline Gender (1) & 0.03 & $\underline{0.36}^{* *}$ & -0.10 & 0.08 & -0.01 & -0.01 & $-0.13^{*}$ & $-0.27^{* *}$ & $0.21^{* *}$ & 0.08 \\
\hline Attended school (2) & & $-\overline{0.24}^{* *}$ & $-0.14^{* *}$ & 0.10 & $0.11^{*}$ & $0.22^{* *}$ & $0.20^{* *}$ & -0.03 & $0.14^{* *}$ & 0.10 \\
\hline Grade point average (3) & & & -0.05 & $0.18^{* *}$ & 0.08 & 0.07 & $-0.12^{*}$ & $-0.16^{* *}$ & $0.13^{*}$ & 0.06 \\
\hline Extracurricular activitie & (4) & & & -0.04 & -0.03 & 0.02 & -0.05 & 0.04 & 0.00 & $0.11^{*}$ \\
\hline Mastery approach goal & & & & & $0.28^{* *}$ & $\underline{0.38}^{* *}$ & $0.23^{* *}$ & $-0.20^{* *}$ & $\underline{0.40}^{* *}$ & $\underline{0.35}^{* *}$ \\
\hline Mastery avoidance goal & (6) & & & & & $\overline{0.37}^{* *}$ & $\underline{0.36^{* *}}$ & $0.14^{* *}$ & $\overline{0.10^{*}}$ & $\overline{0.12} *$ \\
\hline Performance approach & goal (7) & & & & & & $\underline{0.55}^{* *}$ & 0.01 & $0.29^{* *}$ & $0.17^{* *}$ \\
\hline Performance avoidance & goal (8) & & & & & & & $0.17^{* *}$ & $0.20^{* *}$ & -0.03 \\
\hline Work avoidance goal (9) & & & & & & & & & -0.09 & 0.01 \\
\hline Attitudes towards educ & tion $(10$ & & & & & & & & & $\underline{0.32 * *}$ \\
\hline Career decision self-effi & acy (11) & & & & & & & & & \\
\hline
\end{tabular}

Note: ${ }^{*} p<0.05 ;{ }^{* *} p<0.01$; correlations above 0.30 are underlined.

\begin{tabular}{llcc}
\hline Predictors & Step $1 \beta$ & Step $2 \beta$ & Step $3 \beta$ \\
\hline Gender & 0.08 & 0.09 & 0.04 \\
Attended school & 0.05 & 0.04 & 0.03 \\
Grade point average & 0.06 & -0.04 & -0.05 \\
Extracurricular activities & $0.12^{*}$ & $0.12^{*}$ & $0.11^{*}$ \\
Mastery approach goal & - & $0.38^{* *}$ & $0.30^{* *}$ \\
Mastery avoidance goal & - & 0.03 & 0.05 \\
Performance approach goal & - & 0.12 & 0.09 \\
Performance avoidance goal & - & $-0.21^{* *}$ & $-0.23^{* *}$ \\
Work avoidance goal & - & $0.13^{*}$ & $0.12^{*}$ \\
Attitudes towards education & - & - & $0.22^{* *}$ \\
$R$ & 0.15 & 0.43 & 0.47 \\
$R^{2}$ & 0.02 & 0.18 & 0.22 \\
$F(d f)$ & $2.10(4,354)$ & $8.66^{* *}(9,349)$ & $9.84^{* *}(10,348)$ \\
$\Delta R^{2}$ & & 0.16 & 0.04 \\
$F \Delta(d f)$ & & $13.62^{* *}(5,349)$ & $16.87^{* *}(1,348)$ \\
\hline
\end{tabular}

Note: ${ }^{*} p<0.05 ;{ }^{* *} p<0.01 ; \beta$ - standardized regression coefficient; $R$ - multiple correlation coefficient; $R^{2}$ - variance explained by the predictors; $\Delta R^{2}$ - change in $R^{2} ; F$ - F-ratio; $d f$ - degrees of freedom.

Dก TABLE 2

Correlation Matrix for the Tested Variables

(1) TABLE 3

Results of the Hierarchical Regression Analysis Using Career Decision Self-Efficacy as a Criterion
The obtained results revealed mastery approach, performance avoidance and work avoidance goals, as well as participation in extracurricular activities and students' attitudes towards education as statistically significant predictors of career decision self-efficacy that overall explained $22 \%$ of variance. Specifically, whereas the inclusion of control variables in the first step did not result in a statistically significant regression model, in the second step of the analysis students' enrollment in extracurricular activities and three achievement goals (mastery approach, performance avoidance and work avoidance) were revealed as significant predictors of career decision self-efficacy that together explained $18.3 \%$ of 
DRUŠ. ISTRAŽ. ZAGREB GOD. 24 (2015), BR. 3 STR. 387-405

BUBIĆ, A., KRILE, K., KUZMAN, I.: THE IMPÓRTANCE OF.. variance. Among the identified predictors, the strongest regression coefficient was established with respect to mastery approach goals, whereas the lowest regression coefficient was associated with participation in extracurricular activities. However, it has to be noted that first-order correlations did not reveal associations with respect to performance and work avoidance goals with career decision self-efficacy. This suggests a suppressor effect that may be related to the fact that work avoidance, and in particular performance avoidance goals were correlated with both types of mastery and performance approach goals that were all associated with career decision self-efficacy, despite the fact that among them only mastery approach goals were revealed as predictors of career decision self-efficacy. The inclusion of attitudes towards education in the last step of the analysis increased the amount of explained variance by $4 \%$ as this factor was identified as the last significant predictor of career decision self-efficacy.

\section{DISCUSSION}

The present study explored the relevance of high school students' achievement goals and attitudes towards education for their career decision self-efficacy at the end of high school. The obtained results demonstrated that career decision self-efficacy was positively correlated with mastery approach, mastery avoidance and performance approach goals as well as participation in extracurricular activities. Furthermore, the conducted hierarchical regression analysis revealed participation in extracurricular activities, mastery approach, performance avoidance and work avoidance goals as statistically significant predictors of career decision self-efficacy that overall explained $22 \%$ of variance. Among these, the influences of performance and work avoidance goals may reflect suppressor effects, as suggested by the fact that zero-order correlations did not indicate associations between these variables and career decision self-efficacy.

The results obtained in the present study may be interpreted if we consider two main lines of research. First, it is important to take into account previous findings that demonstrate the intricate associations between the academic and vocational domains, suggesting how individuals' academic experiences represent relevant precursors of their vocational behaviors (Brown \& Lent, 2006; Lent et al., 1994, 2002). Consequently, it may be suggested that persons' educational experiences shape their academic self-beliefs and the formulation of educational goals, which then contribute to the development of self-beliefs within the vocational domain. Specifically, these experiences may provide initial standards used for postulating vocational expectations and self-efficacy beliefs, particularly taking into consideration that the outcomes 
DRUŠ. ISTRAŽ. ZAGREB GOD. 24 (2015), BR. 3, STR. 387-405

BUBIĆ, A., KRILE, K., KUZMAN, I.: THE IMPORTANCE OF.. of college and job applications often depend on previous academic achievements and experiences. The second line of research that is of relevance in the present context concerns previous studies that have addressed the construct of self-efficacy and its relationships with achievement orientations. Generally, self-efficacy reflects individuals' beliefs regarding their ability to fulfill particular tasks, and its measures developed in various domains focus on specific performance capabilities rather than general personal psychological characteristics (Bandura, 1986, 1989). In evaluating these abilities, individuals have to compare their accomplishments with certain standards, and typically use mastery criteria of performance in this process (Zimmerman, 2000). Similar considerations of personal competencies also lie at the foundation of achievement motivation, as this construct reflects the purpose of engaging into various activities with the general goal of increasing competence that is evaluated based on different standards associated with specific types of achievement goals (Elliot \& McGregor, 2001).

Furthermore, achievement goals and self-efficacy in the academic domain are related to similar types of educational outcomes. For example, academic self-efficacy influences students' academic achievement, motivation, intrinsic interests, invested efforts and persistence in learning (Bandura, 1986; Multon, Brown, \& Lent, 1991; Robbins et al., 2004; Schunk, Pintrich, \& Meece, 2008). Comparable to this, achievement goals also impact students' academic success, approaches to learning, as well as engagement and persistence in academic activities (Elliot \& McGregor, 2001; Harackiewicz, Barron, Pintrich, Elliot, \& Thrash, 2002). In accordance with these similarities, it has previously been suggested that academic self-efficacy is associated with individuals' achievement goals (Bell \& Kozlowski, 2002; Liem, Lau, \& Nie, 2008; Wigfield, 1994), which was more explicitly recognized within the hierarchical model of achievement motivation (Elliot, 1999). Although these findings and models have been specifically associated with the academic domain, they are also informative for understanding the results of the present study. Accordingly, the patterns of achievement goals' contributions to career decision self-efficacy are consistent with previous reports regarding their influences on academic self-beliefs and behaviors. For example, the revealed influence of mastery approach goals is in accordance with previous studies indicating their associations with numerous positive educational outcomes and consequences (Linnenbrink \& Pintrich, 2002). In contrast, the identified suppressor effect of performance avoidance goals with respect to career decision self-efficacy may be associated with findings indicating a more general complex pattern of relationships among performance goals 
DRUŠ. ISTRAŽ. ZAGREB GOD. 24 (2015), BR. 3 STR. 387-405

BUBIĆ, A., KRILE, K., KUZMAN, I. THE IMPORTANCE OF.. and academic outcomes (Bong, 2001; Middleton \& Midgley, 1997; Midgley, Kaplan, \& Middleton, 2001; Pajares, Britner, \& Valiante, 2000). A similar elaborate interplay among various types of achievement goals is also suggested by the suppressor effect identified with respect to work avoidance goals that have previously been primarily related to negative educational outcomes, e.g., lower academic achievement, lower degree of invested efforts or the use of less efficient learning strategies (Archer, 1994; Dowson \& McInerney, 2001; Harackiewicz, Barron, Carter, Lehto, \& Elliot, 1997; Nolen, 1988). When interpreting the influences of achievement goals on career decision self-efficacy, it is important to consider an alternative speculation suggesting that academic and vocational self-efficacy represent overlapping constructs. However, this suggestion is not in accordance with the general concept of self-efficacy that typically focuses on domain and task-specific performance expectations, nor with the fact that instruments assessing individuals' career decision self-efficacy contain items that differ from those found in academic self-efficacy measures (Bandura, 1986; Betz, 2007; Betz et al., 1996).

In addition to mastery and performance goals, the present study also revealed attitudes towards education as statistically significant predictors of students' career decision self-efficacy. This corroborated our initial hypothesis that attitudes towards education would provide an independent contribution to individuals' career decision self-efficacy, which resonates with previous findings that indicate how recognizing the value and relevance of present opportunities for one's future is associated with different aspects of career decision-making, including career decision self-efficacy (Walker \& Tracey, 2012). Furthermore, our results also confirm previous studies that demonstrated how individuals' attitudes towards school and their perception of relevance of education impact educational attainment and motivation, as well as the formulation of expectations towards the future (Al-Alwan \& Mahasneh, 2014; McNeely et al., 2002; Raboteg et al., 2009; Smith \& Sandhu, 2004; Whitlock, 2006), as they also indicate associations between attitudes towards education and academic achievement as well as mastery and performance achievement goals.

Furthermore, the obtained results indicated participation in extracurricular activities as the final significant predictor of students' career decision self-efficacy. This finding may reflect the fact that students' involvement in such activities typically provides important additional sources of learning experiences that serve as a basis for building global self-competence as well as more specific career decision self-efficacy beliefs (Lent \& Brown, 2013; Lent et al., 1994). Especially if students' choose their extracurricular activities based on own preferences and 
DRUŠ. ISTRAŽ. ZAGREB GOD. 24 (2015), BR. 3, STR. 387-405

BUBIĆ, A., KRILE, K., KUZMAN, I.: THE IMPORTANCE OF.. interests, successful participation in these may provide positive feedback regarding one's abilities, thus influencing self-efficacy and increasing individuals' sense of personal agency (Bandura, 2006). This is in accordance with previous studies that have indicated beneficial effects of participation in extracurricular activities for students' educational and vocational outcomes (McMillan \& Reed, 1994; Rubin, Bommer, \& Baldwin, 2002; Tay, Ang, \& Van Dyne, 2006).

Although it was initially hypothesized that academic achievement would provide a similar significant contribution to career decision self-efficacy, the present study did not support this hypothesis, which may reflect the fact that this variable was assessed in a rather crude manner, using only grade point average. More importantly, the variability of this measure in the present study was rather low, which may be associated with the fact that the participants were all students in their final grade of high school who are motivated to obtain higher grades which may aid them while applying for jobs or colleges. Therefore, the relevance of students' academic success and performance needs to be addressed in more detail in future studies. Similarly, although the influence of school type on career decision self-efficacy was not revealed in the present study, this variable should also be assessed in more detail in future studies, as different types of attended schools provide students with different experiences that may influence some segments of their vocational considerations and decisions. Specifically, it could be speculated that vocational schools provide students with more opportunities to engage in specific types of professional experiences and working practices, which may result in higher career decision self-efficacy of these students. However, this hypothesis should be tested using a wider range of vocational schools, which needs to be addressed in future research. Finally, the results of the present study did not indicate gender contributions to career decision self-efficacy that were expected based on previous results indicating gender differences in some aspects of career decision making (Betz \& Fitzgerald, 1987; Gati et al., 2010; Mau, 2000). However, it is important to note that numerous other studies have failed to demonstrate gender differences with respect to career decision self-efficacy and career decision making more generally (Betz \& Taylor, 2001; Gati et al., 2000; Taylor \& Popma, 1990). Furthermore, it has been argued that the effects of gender on career decision self-efficacy may be indirect, moderated or mediated by other factors (Choi et al., 2012), which resonates with the findings obtained in the present study.

In interpreting the results from the present study, it is important to keep in mind several factors that may limit the 
DRUŠ. ISTRAŽ. ZAGREB GOD. 24 (2015), BR. 3 STR. 387-405

BUBIĆ, A., KRILE, K., KUZMAN, I.

THE IMPÓRTANCE OF.. generalizability of the obtained findings. First, the results of the present study represent correlational data based on self-reports that may be associated with a number of biases and provide limited insights into the potential causal relationships among the investigated constructs (Paulhus \& Vazire, 2007). Taking into account previously reported cross-cultural differences in career decision self-efficacy (Creed et al., 2002), it is important to note that the obtained findings may be culture-specific and need to be verified among adolescents enrolled into different educational systems. Furthermore, in future studies it will be important to explore the contributions of other academically relevant factors such as academic self-efficacy or perception of teacher support to students' autonomy to individuals' career decision self-efficacy and the way they formulate expectations towards future colleges and jobs. Finally, the results of the present study may also be informative for future vocational guidance interventions aimed at adolescents undergoing similar educational transitions. In designing these interventions, it will be important to consider not only individuals' interests and objective abilities, but also their views of own capabilities as well as previous academic experiences and attitudes whose relevance for vocational considerations has been revealed by the present study.

\section{ACKNOWLEDGEMENTS}

The authors thank the Croatian Employment Service for providing assistance in organizing and coordinating data collection within the present study.

\section{REFERENCES}

Al-Alwan, A. F., \& Mahasneh, A. M. (2014). Teachers' self-efficacy as determinant of students' attitudes toward school: A study at the school level. Review of European Studies, 6(1), 171-179. doi:10.5539/res.v6n1p171

Archer, J. (1994). Achievement goals as a measure of motivation in university students. Contemporary Educational Psychology, 19(4), 430-446. doi:10.1006/ceps.1994.1031

Auger, R. W., Blackhurst, A. E., \& Wahl, K. H. (2005). The development of elementary-aged children's career aspirations and expectations. Professional School Counseling, 8(4), 322-329.

Bandura, A. (1986). Social foundations of thought and action: A social cognitive theory. Englewood Cliffs, NJ: Prentice Hall.

Bandura, A. (1989). Regulation of cognitive processes through perceived self-efficacy. Developmental Psychology, 25(5), 729-735. doi:10.1037/ 0012-1649.25.5.729

Bandura, A. (2006). Toward a psychology of human agency. Perspectives on Psychological Science, 1(2), 164-180. doi:10.1111/j.1745-6916. 2006.00011.x 
DRUŠ. ISTRAŽ. ZAGREB GOD. 24 (2015), BR. 3, STR. 387-405

BUBIĆ, A., KRILE, K. KUZMAN, I.: THE IMPORTANCE OF.
Baruch, Y. (2004). Managing careers: Theory and practice. Harlow, UK: Pearson Education.

Bell, B. S., \& Kozlowski, W. J. (2002). Goal orientation and ability: Interactive effects on self-efficacy, performance, and knowledge. Journal of Applied Psychology, 87(3), 497-505. doi:10.1037/0021-9010. 87.3.497

Betz, N. E. (2007). Career self-efficacy: Exemplary recent research and emerging directions. Journal of Career Assessment, 15(4), 403-422. doi:10.1177/1069072707305759

Betz, N. E., \& Fitzgerald, L. F. (1987). The career psychology of women. San Diego, CA: Academic Press.

Betz, N. E., \& Hackett, G. (1986). Applications of self-efficacy theory to understanding career choice behavior. Journal of Social and Clinical Psychology, 4(3), 279-289. doi:10.1521/jscp.1986.4.3.279

Betz, N. E., \& Hackett, G. (2006). Career self-efficacy theory: Back to the future. Journal of Career Assessment, 14(1), 3-11. doi:10.1177/10690 72705281347

Betz, N. E., Klein, K. L., \& Taylor, K. M. (1996). Evaluation of a short form of the career decision-making self-efficacy scale. Journal of Career Assessment, 4(1), 47-57. doi:10.1177/106907279600400103

Betz, N. E., \& Taylor, K. M. (2001). Manual for the career decision self-efficacy scale and CDMSE-Short Form. Columbus: OH: Department of Psychology, Ohio State University.

Betz, N. E., \& Voyten, K. K. (1997). Efficacy and outcome expectations influence career exploration and decidedness. The Career Development Quarterly, 46(2), 179-189. doi:10.1002/j.2161-0045.1997.tb01004.x

Bong, M. (2001). Between- and within-domain relations of academic motivation among middle and high school students: Self-efficacy, task value, and achievement goals. Journal of Educational Psychology, 93(1), 23-34. doi:10.1037/0022-0663.93.1.23

Brown, D. (2002). Career choice and development. San Francisco, CA: Jossey-Bass.

Brown, S. D., \& Lent, R. W. (2006). Preparing adolescents to make career decisions. In F. Pajares \& T. C. Urdan (Eds.), Self-efficacy beliefs of adolescents (pp. 201-223). Greenwich, CT: IAP.

Choi, B. Y., Park, H., Yang, E., Lee, S. K., Lee, Y., \& Lee, S. M. (2012). Understanding career decision self-efficacy: A meta-analytic approach. Journal of Career Development, 39(5), 443-460. doi:10.1177/0894845311 398042

Creed, P. A., Muller, J., \& Patton, W. (2003). Leaving high school: The influence and consequences for psychological well-being and career-related confidence. Journal of Adolescence, 26(3), 295-311. doi:10. 1016/S0140-1971(03)00015-0

Creed, P. A., Patton, W., \& Watson, M. B. (2002). Cross-cultural equivalence of the career decision-making self-efficacy scale-short form: An Australian and South African comparison. Journal of Career Assessment, 10(3), 327-342. doi:10.1177/10672702010003004 
DRUŠ. ISTRAŽ. ZAGREB GOD. 24 (2015), BR. 3 STR. $387-405$

BUBIĆ, A., KRILE, K., KUZMAN, I.:

THE IMPÓRTANCE OF..
Dowson, M., \& McInerney, D. M. (2001). Psychological parameters of students' social and work avoidance goals: A qualitative investigation. Journal of Educational Psychology, 93(1), 35-42. doi:10.1037/00220663.93.1.35

Eccles, J. S. (2005). Subjective task value and the Eccles et al. model of achievement-related choices. In A. J. Elliot \& C. S. Dweck (Eds.), Handbook of competence and motivation (pp. 105-121). New York, NY: Guilford Publication.

Eccles, J. S., \& Wigfield, A. (2002). Motivational beliefs, values, and goals. Annual Review of Psychology, 53(1), 109-132. doi:10.1146/annurev. psych.53.100901.135153

Elliot, A. J. (1999). Approach and avoidance motivation and achievement goals. Educational Psychologist, 34(3), 169-189. doi:10.1207/s1532 6985ep3403_3

Elliot, A. J., \& McGregor, H. A. (2001). A 2 × 2 achievement goal framework. Journal of Personality and Social Psychology, 80(3), 501-519. doi:10.1037/0022-3514.80.3.501

Gall, T. L., Evans, D. R., \& Bellerose, S. (2000). Transition to first-year university: Patterns of change in adjustment across life domains and time. Journal of Social and Clinical Psychology, 19(4), 544-567. doi:10. 1521/jscp.2000.19.4.544

Galotti, K. M. (1999). Making a "major" real-life decision: College students choosing an academic major. Journal of Educational Psychology, 91(2), 379-387. doi:10.1037/0022-0663.91.2.379

Gati, I., Landman, S., Davidovitch, S., Asulin-Peretz, L., \& Gadassi, R. (2010). From career decision-making styles to career decision-making profiles: A multidimensional approach. Journal of Vocational Behavior, 76(2), 277-291. doi:10.1016/j.jvb.2009.11.001

Gati, I., Osipow, S. H., Krausz, M., \& Saka, N. (2000). Validity of the Career Decision-Making Difficulties Questionnaire: Counselee versus career counselor perceptions. Journal of Vocational Behavior, 56(1), 99-113. doi:10.1006/jvbe.1999.1710

Gianakos, I. (1999). Patterns of career choice and career decision-making self-efficacy. Journal of Vocational Behavior, 54(2), 244-258. doi:10.1006/ jvbe.1998.1668

Gysbers, N. C., Heppner, M., \& Johnson, J. A. (1998). Career counseling. Boston, MA: Allyn \& Bacon.

Harackiewicz, J. M., Barron, K. E., Carter, S. M., Lehto, A. T., \& Elliot, A. J. (1997). Predictors and consequences of achievement goals in the college classroom: Maintaining interest and making the grade. Journal of Personality and Social Psychology, 73(6), 1284-1295. doi:10.1037/00223514.73.6.1284

Harackiewicz, J. M., Barron, K. E., Pintrich, P. R., Elliot, A. J., \& Thrash, T. M. (2002). Revision of achievement goal theory: Necessary and illuminating. Journal of Educational Psychology, 94, 638-645.

Hartung, P. J., Porfeli, E. J., \& Vondracek, F. W. (2005). Child vocational development: A review and reconsideration. Journal of Vocational Behavior, 66(3), 385-419. doi:10.1016/j.jvb.2004.05.006 
DRUŠ. ISTRAŽ. ZAGREB GOD. 24 (2015), BR. 3, STR. 387-405

BUBIĆ, A., KRILE, K. KUZMAN, I.: THE IMPORTANCE OF..
Helwig, A. A. (1998). Occupational aspirations of a longitudinal sample from second to sixth grade. Journal of Career Development, 24(4), 247-265. doi:10.1023/A:1025085830778

Kaliski, P. K., Finney, S. J., \& Horst, S. J. (2006). Does socioeconomic status influence achievement goal adoption? An investigation of group difference using structured means modeling. Presented at the Meeting of the American Educational Research Association, San Francisco, CA.

Lent, R. W., \& Brown, S. D. (2006). On conceptualizing and assessing social cognitive constructs in career research: A measurement guide. Journal of Career Assessment, 14(1), 12-35. doi:10.1177/1069072705281364

Lent, R. W., \& Brown, S. D. (2013). Social cognitive model of career self-management: Toward a unifying view of adaptive career behavior across the life span. Journal of Counseling Psychology, 60(4), 557-568. doi:10.1037/a0033446

Lent, R. W., Brown, S. D., \& Hackett, G. (1994). Toward a unifying social cognitive theory of career and academic interest, choice, and performance. Journal of Vocational Behavior, 45(1), 79-122. doi:10.1006/ jvbe.1994.1027

Lent, R. W., Brown, S. D., \& Hackett, G. (2002). Social cognitive career theory. In D. Brown \& associates (Eds.), Career choice and development (Vol. 4, pp. 255-311). San Francisco, CA: Wiley.

Liem, A. D., Lau, S., \& Nie, Y. (2008). The role of self-efficacy, task value, and achievement goals in predicting learning strategies, task disengagement, peer relationship, and achievement outcome. Contemporary Educational Psychology, 33(4), 486-512. doi:10.1016/j.cedpsych. 2007.08.001

Linnenbrink, E. A., \& Pintrich, P. R. (2002). Motivation as an enabler for academic success. School Psychology Review, 31(3), 313-327.

Mau, W. C. (2000). Cultural differences in career decision-making styles and self-efficacy. Journal of Vocational Behavior, 57(3), 365-378. doi:10.1006/jvbe.1999.1745

McMillan, J. H., \& Reed, D. F. (1994). At-risk students and resiliency: Factors contributing to academic success. The Clearing House, 67(3), 137-140. doi:10.1080/00098655.1994.9956043

McNeely, C. A., Nonnemaker, J. M., \& Blum, R. W. (2002). Promoting school connectedness: Evidence from the national longitudinal study of adolescent health. Journal of School Health, 72(4), 138-146. doi:10. 1111/j.1746-1561.2002.tb06533.x

Middleton, M. J., \& Midgley, C. (1997). Avoiding the demonstration of lack of ability: An underexplored aspect of goal theory. Journal of Educational Psychology, 89(4), 710-718. doi:10.1037/0022-0663.89.4.710

Midgley, C., Kaplan, A., \& Middleton, M. (2001). Performance-approach goals: Good for what, for whom, under what circumstances, and at what cost? Journal of Educational Psychology, 93(1), 77-86. doi:10.1037/0022-0663.93.1.77

Multon, K. D., Brown, S. D., \& Lent, R. W. (1991). Relation of self-efficacy beliefs to academic outcomes: A meta-analytic investigation. Journal of Counseling Psychology, 38(1), 30-38. doi:10.1037/00220167.38.1.30 
DRUŠ. ISTRAŽ. ZAGREB GOD. 24 (2015), BR. 3 STR. $387-405$

BUBIĆ, A., KRILE, K., KUZMAN, I.

THE IMPÓRTANCE OF..
Nicholls, J. G., Cobb, P., Wood, T., Yackel, E., \& Patashnick, M. (1990). Assessing students' theories of success in mathematics: Individual and classroom differences. Journal for Research in Mathematics Education, 21(2), 109-122. doi:10.2307/749138

Nolen, S. B. (1988). Reasons for studying: Motivational orientations and study strategies. Cognition and Instruction, 5(4), 269-287. doi:10. 1207/s1532690xci0504_2

Pajares, F., Britner, S. L., \& Valiante, G. (2000). Relation between achievement goals and self-beliefs of middle school students in writing and science. Contemporary Educational Psychology, 25(4), 406-422. doi:10.1006/ceps.1999.1027

Paulhus, D. L., \& Vazire, S. (2007). The self-report method. In R. W. Robins, R. C. Fraley, \& R. F. Krueger (Eds.), Handbook of research methods in personality psychology (pp. 224-239). New York: Guilford Press.

Pekrun, R., Elliot, A. J., \& Maier, M. A. (2006). Achievement goals and discrete achievement emotions: A theoretical model and prospective test. Journal of Educational Psychology, 98(3), 583-597. doi:10.1037/00220663.98.3.583

Pekrun, R., Elliot, A. J., \& Maier, M. A. (2009). Achievement goals and achievement emotions: Testing a model of their joint relations with academic performance. Journal of Educational Psychology, 101(1), 115-135. doi:10.1037/a0013383

Raboteg-Šarić, Z., Šakić, M., \& Brajša-Žganec, A. (2009). Kvaliteta života u osnovnoj školi: Povezanost sa školskim uspjehom, motivacijom i ponašanjem učenika (Quality of school life in primary schools: Relations with academic achievement, motivation and students' behavior). Društvena istraživanja, 18(4-5), 697-716.

Robbins, S. B., Lauver, K., Le, H., Davis, D., Langley, R., \& Carlstrom, A. (2004). Do psychosocial and study skill factors predict college outcomes? A meta-analysis. Psychological Bulletin, 130(2), 261-288. doi:10. 1037/0033-2909.130.2.261

Rovan, D. (2011). Odrednice odabira ciljeva pri učenju matematike u visokom obrazovanju (Achievement goals in learning mathematics in higher education) (Doctoral Thesis). Faculty of Humanities and Social Sciences, University of Zagreb, Zagreb.

Rovan, D. (2012). Povezanost ulaganja truda u učenje matematike s ciljevima postignuća, uvjerenjima i osobinama studenata (The relationship of effort in learning mathematics to achievement goals, beliefs and personality traits). Suvremena psihologija, 15(1), 81-94.

Rovan, D., Pavlin-Bernardić, N., \& Vlahović-Štetić, V. (2013). Struktura motivacijskih uvjerenja $\mathrm{u}$ matematici i njihova povezanost $\mathrm{s}$ obrazovnim ishodima (The structure of students' motivational beliefs in mathematics and their relation to academic outcomes). Društvena istraživanja, 22(3), 475-495. doi:10.5559/di.22.3.05

Rubin, R. S., Bommer, W. H., \& Baldwin, T. T. (2002). Using extracurricular activity as an indicator of interpersonal skill: Prudent evaluation or recruiting malpractice? Human Resource Management, 41(4), 441-454. doi:10.1002/hrm.10053 
DRUŠ. ISTRAŽ. ZAGREB GOD. 24 (2015), BR. 3, STR. 387-405

BUBIĆ, A., KRILE, K., KUZMAN, I.: THE IMPORTANCE OF..
Sampson, J. P. (1999). Integrating Internet-based distance guidance with services provided in career centers. The Career Development Quarterly, 47(3), 243-254. doi:10.1002/j.2161-0045.1999.tb00734.x

Savickas, M. L., Nota, L., Rossier, J., Dauwalder, J.-P., Duarte, M. E., Guichard, J., Van Vianen, A. E. (2009). Life designing: A paradigm for career construction in the 21st century. Journal of Vocational Behavior, 75(3), 239-250. doi:10.1016/j.jvb.2009.04.004

Schunk, D. H., Pintrich, P. R., \& Meece, J. L. (2008). Motivation in education: Theory, research, and applications. Upper Saddle River, NJ: Merrill-Prentice Hall.

Smith, D. C., \& Sandhu, D. S. (2004). Toward a positive perspective on violence prevention in schools: Building connections. Journal of Counseling \& Development, 82(3), 287-293. doi:10.1002/j.1556-6678.2004. tb00312.x

Tay, C., Ang, S., \& Van Dyne, L. (2006). Personality, biographical characteristics, and job interview success: A longitudinal study of the mediating effects of interviewing self-efficacy and the moderating effects of internal locus of causality. Journal of Applied Psychology, 91(2), 446-453. doi:10.1037/0021-9010.91.2.446

Taylor, K. M., \& Popma, J. (1990). An examination of the relationships among career decision-making self-efficacy, career salience, locus of control, and vocational indecision. Journal of Vocational Behavior, 37(1), 17-31. doi:10.1016/0001-8791(90)90004-L

Trice, A. D., Hughes, M. A., Odom, C., Woods, K., \& McClellan, N. C. (1995). The origins of children's career aspirations: IV. Testing hypotheses from four theories. The Career Development Quarterly, 43(4), 307-322. doi:10.1002/j.2161-0045.1995.tb00436.x

Walker, T. L., \& Tracey, T. J. (2012). The role of future time perspective in career decision-making. Journal of Vocational Behavior, 81(2), 150-158. doi:10.1016/j.jvb.2012.06.002

Whitlock, J. L. (2006). Youth perceptions of life at school: Contextual correlates of school connectedness in adolescence. Applied Developmental Science, 10(1), 13-29. doi:10.1207/s1532480xads1001_2

Wigfield, A. (1994). Expectancy-value theory of achievement motivation: A developmental perspective. Educational Psychology Review, 6(1), 49-78. doi:10.1007/BF02209024

Wigfield, A., \& Eccles, J. S. (2000). Expectancy-value theory of achievement motivation. Contemporary Educational Psychology, 25(1), 68-81. doi:10.1006/ceps.1999.1015

Wigfield, A., \& Eccles, J. S. (2002). The development of competence beliefs, expectancies for success, and achievement values from childhood through adolescence. In A. Wigfield \& J. S. Eccles (Eds.), Development of achievement motivation (pp. 91-120). Elsevier.

Zimmerman, B. J. (2000). Self-efficacy: An essential motive to learn. Contemporary Educational Psychology, 25(1), 82-91. doi:10.1006/ceps.1999. 1016 
DRUŠ. ISTRAŽ. ZAGREB GOD. 24 (2015), BR. 3, STR. $387-405$

BUBIĆ, A., KRILE, K., KUZMAN, I.:

THE IMPÓRTANCE OF..
Važnost ciljeva dostignuća i stavova o obrazovanju u objašnjenju samoefikasnosti u odlučivanju o karijeri kod adolescenata

Andreja BUBIĆ

Filozofski fakultet, Split

Katarina KRILE, Ivana KUZMAN

Hrvatski zavod za zapošljavanje, Dubrovnik

Dosadašnja istraživanja pokazala su značajnost uvjerenja pojedinaca o njihovim sposobnostima vezanim uz upravljanje karijerom, odnosno njihove samoefikasnosti u odlučivanju o karijeri, za profesionalni uspjeh. U provedenom istraživanju ta su uvjerenja ispitana među skupinom učenika završnih razreda srednje škole, koji će se uskoro naći u situaciji važnoga profesionalnog odabira posla ili fakulteta. $U$ istraživanju su ispitani i učenički ciljevi dostignuća i stavovi o obrazovanju te je istražena njihova povezanost sa samoefikasnosti u odlučivanju o karijeri. Dobiveni rezultati izdvojili su ciljeve ovladavanja uključivanjem, izvedbom, izbjegavanjem rada, kao i stavove prema obrazovanju te sudjelovanje u izvannastavnim aktivnostima kao statistički značajne prediktore samoefikasnosti u odlučivanju o karijeri. Ovi rezultati upućuju na važnost akademskih iskustava za razvoj samoefikasnosti u odlučivanju o karijeri te nude nove spoznaje o složenoj međuovisnosti obrazovnih i karijernih procesa. Oni stoga mogu biti informativni za osmišljavanje budućih programa karijernoga savjetovanja za adolescente koji prelaze na fakultet ili tržište rada, kao i pojedince koji prolaze slične karijerne tranzicije.

Ključne riječi: ciljevi dostignuća, razvoj karijere, samoefikasnost u odlučivanju o karijeri, stavovi prema obrazovanju 